N $73 \quad 31694$

NASA TECHNICAL MEMORANDUM

NASA TM X-68296

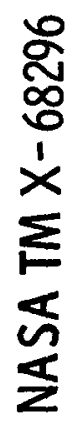

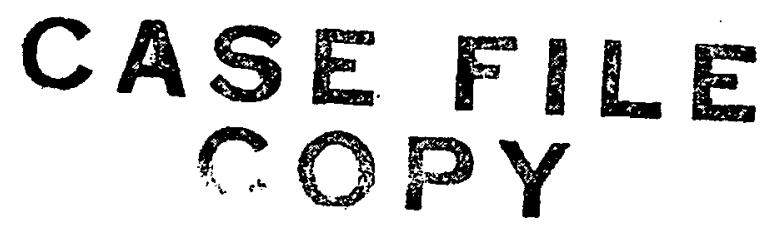

AN 8-CM ELECTRON BOMBARDMENT THRUSTER FÖR AUXILIARY PROPULSION

by Wayne R. Hudson and Bruce A. Banks

Lewis Research Center

Cleveland, Ohio 44135

i TECHNICAL PAPER proposed for presentation at

Tenth Electric Propulsion Conference sponsored by the American Institute of Aeronautics and Astronautics

Lake Tahoe, Nevada, October 31-November 2, 1973 


\section{AN 8-CM ELECTRON BOMBARDMENT THRUSTER FOR AUXILIARY PROPULSION}

Wayne R. Hudson and Bruce A. Banks

National Aeronautics and Space Administration

Lewis Research Center

cleveland, Ohio

\section{Abstract}

Thruster size, beam current level, and specific impulse trade-offs are considered for mercury electron bombardment ion thrusters to be used for north-south station keeping of geosynchronous spacecraft. An 8-cm diameter thruster operating at 2750 seconds specific impulse at thrust levels of $4.4 \mathrm{mN}(1 \mathrm{mlb})$ to $8.9 \mathrm{mN}(2 \mathrm{mlb})$ with a design life of 20000 hours and 10000 cycles is being deve1oped. The thruster will have a dished two-grid system capable of thrust vectoring of \pm 10 degrees in two or thogonal directions. A preliminary thruster has been fabricated and rested; thruster performance characteristics have been determined at $4.45,6.68$, and 8.90 millinewtons.

\section{Introduction}

The Lewis Research Center is developing an eight centimeter diameter, 2000 to 3000 second specific impulse mercury bombardment ion thruster, capable of operating at thrust levels up to 8.9 millinewtons ( 2 millipounds) with a design life of 20000 hours and 10000 cycles. The ion extraction system will be a dished two-grid system with thrust vectoring capability of +10 degrees in two orthogonal directions.

The initial thruster system design was based on technology developed for the structurally integrated five centimeter diameter ion thruster. $(1,2)$ An eight centimeter diameter thruster was chosen for the Lewis Research Center auxiliary propulsion program because it represents a favorable compromise between weight and power restrictions, and operational life and thrust requirements.

Although the eight centimeter diameter ion thruster is an auxiliary propulsion device, its prime utilization within the Lewis Research Center is as a low cost test bed for prime propulsion thruster technology. Thruster components such as grid roll translation vectoring systems, impregnated cathode inserts, pyrolytic graphite baffles, and back plates, high voltage pulse starting and screen anodes currently being evaluatec on an eight cm diameter thruster are directly applicable to larger diameter thrusters.

This paper also describes a computer analysis of thruster-mission requirements that supports the choice of an eight centimeter thruster for stationkeeping applications on near term and future geosynchronous satellite missions. The components comprising the thruster system are described herein, along with the preliminary design and optimization. Performance data for the discharge chamber, the beam extraction system, and entire thruster are included.

\section{Selection of Specific Impulse, Thruster Diameter} and Ion Beam Current

The most probable use of auxiliary propulsion ion thrusters for geosynchronous spacecraft of 500 to $2000 \mathrm{~kg}$ mass is north-south station keeping. other thruster functions such as east-west stationkeeping and momentum wheel dumping typically represent much reduced total impulse requirements. $(3,4)$ Choice of the optimum thruster size and operating conditions should then be determined by the northsouth station-keeping requirements and thruster 1ifetime considerations.

A structurally integrated $5 \mathrm{~cm}$ diameter mercury ion thruster (SIT-5) with dual axis electrostatic vector grids producing $1.78 \mathrm{mN}(0.4 \mathrm{mlb})$ thrust has demonstrated grid dependent thruster lifetime of 7688 hours. $(1,2,5)$ Figure 1 shows a plot of the maximum north-south station-keeping capability of a spacecraft using two of these thrusters and assuming a grid dependent thruster lifetime of 7500 hours. The plot indicates that a spacecraft whose mass and mission length are on or below the plotted curves can be north-south station kept with the thrust level indicated. Those spacecraft whose coordinates are above the curves cannot be north-south station-kept because efther the thrust or thruster lifetime is inadequate. Two thrusters are assuned to share equally in the station-keeping duty. There is enough thrusting time (without allowing more than $7500 \mathrm{hr}$ operation on the $5 \mathrm{~cm}$ thrusters) and thrust for one thruster to perform the north-south station keeping in the event of an initial thruster system fallure. This provides the redundancy required to assure mission success.

Also plotted in figure 1 are the north-south station-keeping capabilities of similarly redundant $4.45 \mathrm{mN}(1 \mathrm{mlb})$ and $8.90 \mathrm{mN}(2 \mathrm{mlb})$ thrust level systems. These thrusters with higher thrust levels are assumed to use grid systems capable of 20000 hours life. This is consistent with lifetime projections based on a $5000 \mathrm{hr}$ test of a misalignment vector grid.(6) As can be seen from figure 1 , missions with much heavier spacecraft and longer mission lifetimes can be achieved with the use of the $4.45 \mathrm{mN}(1 \mathrm{mlb})$ and $8.90 \mathrm{mN}(2 \mathrm{mlb})$ thrust levels. Choice of the optimum thruster diameter, ion beam current, and specific impulse depends upon the spectfic mission and trade offs of weight, power, lifetime, and reliability.

To assess the various trade-offs, equations have been generated which are consistent with known or expected system masses, efficiencies, power leve1s, and ion beam currents. Two thrusters were assumed to share equally in the north-south station keeping function. Each thruster was redundant in that it could completely perform the north-south station-keeping in the event of an initial thruster system failure. Two different thruster system configurations were considered. The first configuration had a total mass of $M_{I}$ and consisted of two independent thruster systems (two thrusters, two full propellant tanks, and two power conditioners) and the mass associated with the required solar cell array. The solar array was assumed to have an energy to mass ratio of 16.2 watts $/ \mathrm{kg}$ ( 7.34 watts/ 1b). This included the weight and power penalties 
assoclated with the solar panel blanket, deployment mechanism, enclosure, support structure, orientation mechanism, slip rings, solar cell degradation, and seasonal panel inclination. The second thruster system configuration represented by mass $M_{c}$ was identical to the first with the exception of having interconnected propellant tanks. This reduced the propellant requirement in that redundancy is achieved by allowing all the propellant to be consumed by one thruster in the event of failure of the other thruster.

The equations for the various system masses; thruster input power, $\mathrm{P}$; eV/ion, $\varepsilon_{\mathrm{I}}$; propellant utilization, $n_{U}$; power conditioner efficiency, $\eta_{p c}$, Ion beam current, $J_{B}$; and thruster operating time, $T$; are given below:

$$
\begin{aligned}
& M_{I}=2\left(M_{T H}+M_{T K I}+M_{p c}+M_{H g}\right)+M_{s p} \\
& M_{c}=2\left(M_{T H}+M_{T K C}+M_{p c}\right)+M_{H g}+M_{s p} \\
& \mathrm{M}_{\mathrm{TH}}=(0.227) \mathrm{D} \\
& \mathrm{M}_{\mathrm{TKI}}=(0.1235) \mathrm{M}_{\mathrm{Hg}}+0.151 \\
& \mathrm{M}_{\mathrm{TKC}}=(0.1235) \mathrm{M}_{\mathrm{Hg}}+0.264 \\
& \mathrm{M}_{\mathrm{Hg}}=\frac{3.902 \mathrm{KYD}^{2}}{111.7+\mathrm{D}} \operatorname{arc} \sin \left[\frac{1.209 \mathrm{M}_{\mathrm{sc}}(111.7+\mathrm{D})}{\mathrm{KD}^{2} \mathrm{I}_{\mathrm{sp}} \cos \phi}\right] \\
& M_{s p}=\frac{P}{16.2} \\
& M_{p c}=2.501 n P-5.628 \\
& \mathrm{P}=10+1.8 \mathrm{D}+1.12 \times 10^{-3} \mathrm{kD}^{2}\left[\frac{\mathrm{I}_{\mathrm{sp}}^{2}}{(67+0.6 \mathrm{D})^{2}}+395-9 \mathrm{D}\right] \\
& \varepsilon_{I}=395-9 D \\
& \eta_{\mathrm{L}}=0.67+0.006 \mathrm{D} \\
& \eta_{\mathrm{pc}}=0.671+0.0303 \ln \mathrm{P} \\
& J_{B}=1.12 \times 10^{-3} \mathrm{KD}^{2} \\
& T=2790 Y \arcsin \left[\frac{0.6045 \mathrm{M}_{\mathrm{sc}}(111.7+\mathrm{D})}{\mathrm{KD}^{2} \mathrm{I}_{\mathrm{sp}} \cos \phi}\right]
\end{aligned}
$$

The ion beam factor $\mathrm{K}$ is a constant proportional to the ion beam current density. A value of $\mathrm{K}=1$ represents an average ion beam current density of $1.43 \times 10^{-3} \mathrm{~A} / \mathrm{cm}^{2}$ (assuming the ion beam diameter equals the thruster diameter). The equations are in general semiempirical in that they produce observed or expected values with smooth transitions between known data points. The equations for $\mathrm{M}_{\mathrm{Hg}}$ and $\mathrm{T}$ are also a result of theoretical mission analysis in addition to empirical data. Table 1 is a comparison of some performance parameters, efficiencies, and subsystem masses for various thruster diameters, using the previously listed equations.
A computer search was made using the above equations to find the values of thruster diameter, $D$; Ion beam current factor, $K$; and specific impulse, $I_{s p}$; that ylelded the minimum total system mass values ( $M_{I}$ and $M_{c}$ ) for any given spacecraft mass, $M_{s c}$; mfssion length, $Y$; and thruster orientation angle from north or south, $\phi$. As a result of this search, based on minimizing only total system mass without regard to component rellability and lifetime, the optimal conflgurations consisted of small diameter thrusters (4 cm dlam for a $1000 \mathrm{~kg}$ spacecraft on a $5 \mathrm{yr}$ mission) operating at high specific impulses ( 4000 to $5000 \mathrm{sec}$ ) and at high ion beam current levels $(K=1.8$ to 2.2$)$. Since a specific impulse near 2750 seconds is advantageous with respect to operational reliability and lifetime considerations, a second computer search was made with $I_{s p}=2750 \mathrm{sec}, Y=5 \mathrm{yr}$, and $\phi=0$. This choice of $I_{S p}$ appears acceptable since the thrust system mass is only moderately dependent on $I_{\text {sp }}$ as shown in figure 2. Table 2 is a list of the minimum total system masses for various spacecraft masses for the second search. Also given are values of thruster diameter, $D$; ion beam current factor, $\mathrm{K}$; ion beam current, $\mathrm{J}_{\mathrm{B}}$; and thruster operating time, T. For two thrusters performing northsouth station-keeping of a $2000 \mathrm{~kg}$ spacecraft an $8 \mathrm{~cm}$ diameter thruster was found to be the optimum.

Table 3 is a list of the resulting minimum total thruster system mass for various spacecraft masses assuming the use of $8 \mathrm{~cm}$ diameter thrusters $(D=8 \mathrm{~cm})$ for all the spacecraft masses with $\mathrm{I}_{\mathrm{sp}}=2750 \mathrm{sec}, \phi>0$ and $\mathrm{Y}=5 \mathrm{yr}$. As can be seen by comparing tables 2 and 3 , the use of $8 \mathrm{~cm}$ diameter thrusters for all spacecraft masses from 500 to $2000 \mathrm{~kg}$ represents an attractive single size system. The $8 \mathrm{~cm}$ thruster system is in the worst case heavier than the optimum size thruster of table 2 by only $2.7 \mathrm{~kg}(11 \%)$. In all cases the interconnected propellant tankage systems were between 21 and 27 percent lighter than the independent tankage systems. For near term and future heavier spacecraft masses the $8 \mathrm{~cm}$ thruster appears to be a favorable compromise of thruster lifetime, thrust capability, and near optimum total system mass.

\section{Thruster Components}

\section{D1scharge Chamber}

The thruster configuration in its current state of evolution is shown in cross sectional view, figure 3 . The starting point for the $8 \mathrm{~cm}$ thruster was based on a $8 / 5$ scale of the SIT-5 thruster. Like the SIT -5 thruster the $8 \mathrm{~cm}$ diameter thruster has a cylindrical shell engine body with a concentric anode. The discharge chamber diameter is $9.4 \mathrm{~cm}$ and the anode diameter is $8.6 \mathrm{~cm}$. Chamber and anode lengths are $7.75 \mathrm{~cm}$ and $6.05 \mathrm{~cm}$, respectively.

The magnetic circult consists of a magnetic pole piece surrounding the cathode region, the thruster back plate, and the anode pole piece. The cathode pole piece is $1.2 \mathrm{~cm}$ long and $2.1 \mathrm{~cm}$ in diameter. A tantalum baffle was mounted even with the end of the cathode pole piece. The anode pole piece has a truncated conical surface which makes an angle of $20^{\circ}$ with respect to the thruster axis and is $0.48 \mathrm{~cm}$ long. Its smallest diameter is $8.4 \mathrm{~cm}$. The backplate and the anode pole piece are 
linked magnetically with twelve $0.32 \mathrm{~cm}$ diameter rod magnets. The magnetic field along the axis thruster varies from 75 gauss near the baffle to near 0 gauss at the grid plane.

\section{Cathode}

The main cathode configuration is shown in figure 4. It is a $0.32 \mathrm{~cm}$ diameter tantalum tube with a $0.25 \mathrm{~mm}$ orifice in a two percent thoriated tungsten tip. Two types of inserts are under investigation - the SERT II (Space Electric Rocket Test) barium carbonate coated rolled tantalum foil insert and an impregnated porous tungsten insert. Reference 7 describes the impregnated insert. The insert aids in the initiation of the cathode discharge and in the cathode emission during operation. The cathode tip is heated by a flame sprayed alumina encapsulated tungsten rhenium heater. All cathodes are of the enclosed keeper design. The keeper electrode mounts on a cylindrical alumina sleeve. The sleeve in turn slides over three layers of tantalum foil $(0.015 \mathrm{~mm}$ thick) radiation shielding which is wrapped around the flame sprayed alumina. The keeper is positioned $1.5 \mathrm{~mm}$ from the cathode tip and has an orifice $2.5 \mathrm{~mm}$ in diameter. Mercury vapor is supplied to the cathode by a porous tungsten vaporizer. (8) The flow rates are determined by measuring the time rate of change of Hg leve1 in a $0.5 \mathrm{~mm}$ diameter burette.

It was possible to ignite the cathode discharge with less than 20 watts of tip heater power, 500 volts applied to the keeper electrode, and 80-90 equivalent milliamperes of mercury flow. An alternate approach using a high voltage pulse technique is being explored for cathode starting. (9) If proper1y activated, cathodes such as shown in figure 4 can operate without tip heater power.

\section{Neutralizer}

An enclosed hollow cathode neutralizer similar to the main cathode was used to neutralize the beam. It was positioned $2.5 \mathrm{~cm}$ downstream and $2.5 \mathrm{~cm}$ radially outward from edge of the active grid area. The neutralizer keeper orifice was $1.25 \mathrm{~mm}$ in diameter. The impregnated porous tungsten insert was also tested in the neutralizer. The neutralizer was generally operated with 5 to 6 watts of tip heat. This power may be saved by using additional radiation shielding. The neutralizer was operated at several mercury flow rates between 3 and $10 \mathrm{~mA}$. The neutralizer floating potential (i.e., the potential of the neutralizer with respect to ground) changed from -7 volts at the lowest neutralizer mercury flow rates $(4 \mathrm{~mA})$ to -12 volts at the highest (12 mA).

\section{Beam Extraction System}

The beam extraction system consists of two dished grids with matched hexagonal arrays of holes. The grid active area is defined by an $8 \mathrm{~cm}$ diameter. The grids were simultaneously hydroformed to a depth of $0.25 \mathrm{~cm}$; this corresponds to a radius of curvature of about $30 \mathrm{~cm}$. The screen grid is $0.40 \mathrm{~mm}$ thick and has an open area of $72.5 \%$, which results from $1.97 \mathrm{~mm}$ diameter holes spaced $2.21 \mathrm{~mm}$ apart. The accelerator grid is 0.52 mo thick, and it has $1.69 \mathrm{~mm}$ diameter holes spaced $2.21 \mathrm{~mm}$ apart (51\% open area). In the tests described in this paper, the grids used were permanently mounted with a $0.50 \mathrm{~mm}$ gap between them. A grid system which is capable of vectoring the grid \pm 10 degrees along two mutually perpendicular directions is currently being developed. The thrust vectoring will be accomplished by roll translation of the accelerator grid with respect to the screen grid. (10,11)

\section{Preliminary Thruster Performance}

In all the thruster testing the electrical circuit shown in figure 5 was used. The anode was held at the net accelerating voltage, $v_{I}$. The cathode was negatively biased by the $\Delta v_{I}$ supply and the neutrallzer floating potential was measured between the neutralfzer and factlity ground.

The vacuum factlity used for this investigation was $4.5 \mathrm{~m}$ long by $1.5 \mathrm{~m}$ in diameter. The thruster test chamber was connected to the facility through a $0.3 \mathrm{~m}$ gate valve. The factlity was maintained at $10^{-6}$ torr during thruster operation.

As mentioned earlier, the preliminary thruster geometry was determined by an $8 / 5$ scaling of the SIT-5 geometry. This starting point proved very successful, ylelding higher utilizations and lower discharge losses than achleved by the SIT-5 thruster with electrostatic vector grids. Subsequent varlations of the chamber length, anode diameter, magnetic field, cathode pole pleces and baffles, and screen pole piece geometry Improved thruster propellant utilization a few percent. The only significant change from direct scale was an increase in the anode diameter to $8.6 \mathrm{~cm}$, and this modification was primarily to enhance the thrusters capabilities in the $8.9 \mathrm{mN}(2 \mathrm{mlb})$ thrust range.

The SIT-5 thruster operating conditions and the $8 \mathrm{~cm}$ thruster program goals are listed in table 4. Also presented are the operating characteristics of the $8 \mathrm{~cm}$ thruster operated at both the $4.45 \mathrm{mN}(1 \mathrm{mlb})$ and the $8.9 \mathrm{mN}(2 \mathrm{mlb})$ thrust levels.

The $8 \mathrm{~cm}$ ideal thrust goal is $5.07 \mathrm{mN}$ (1.14 mlb) rather than $4.45 \mathrm{mN}(1 \mathrm{mlb})$. The additional $0.62 \mathrm{mN}(0.14 \mathrm{mlb})$ is intended to more than offset anticipated thrust losses due to beam divergence and double lonization. This level was easily attained and surpassed. The thruster was able to run well at $8.9 \mathrm{mN}(2 \mathrm{mlb})$ of thrust. The SIT-5 propellant utilization was $65 \%$. The $8 \mathrm{~cm}$ thruster has, even in its preliminary stage, reached $72.7 \%$. The increase in thruster diameter and use of a dished grid (rather than the electrostatic vector grid) system is probably responsible for a large portion of the utilization improvement. The program goal of $80.6 \%$ should be attained by thruster modifications which are mentioned later in this paper. Significant decreases in the power to thrust ratio have also been obtained. The SIT-5 operated at 175 watts/m1b and preliminary $8 \mathrm{~cm}$ has required only 135 watts/mlb. Further improvements can be expected from improved radiation shielding of the main cathode and neutralizer thereby reducing the required vaporizer heater power.

Improved discharge chamber performance was obtained at the $8.9 \mathrm{mN}(2 \mathrm{mlb})$ thrust level. Total propellant utilizations greater than $80 \%$ were easily reached at discharge losses of $382 \mathrm{eV} /$ ion. At these conditions the power to thrust ratio was 112.5 watts/m1b. These values were obtained without any effort to optimize the thruster for opera- 
tion at the higher thrust levels.

The discharge chamber performance as a function of propellant utilization is shown in figure 6. For all of the data shown, the net accelerating potential was 1200 volts and the accelerator grid voltage was -500 volts. At the maximum utilization of $74.5 \%$, the discharge losses were $607 \mathrm{eV} / 1$ ion. At discharge losses of $320 \mathrm{eV} / 1$ ion (slightly less than the program goal) the prope1lant utilization was $65 \%$. Data points are also shown for operation at $6.9 \mathrm{mN}(1.5 \mathrm{mlb})$ and $8.9 \mathrm{mN}$ $(2.0 \mathrm{~m} 1 \mathrm{~b})$. The thruster was power supply 1 fmited at $8.9 \mathrm{mN}(2.0 \mathrm{mlb})$. These preliminary data points indicate that the thruster runs more efficiently at higher thrust levels, probably because of the constant neutral loss effect of reference 12 .

Figure 7 is the current-voltage characteristic of the discharge in the lonization chamber at 104 milliamperes of equivalent $\mathrm{Hg}$ flow. Data is also shown for the discharge characteristic at $157 \mathrm{~mA}$ of mercury flow.

In figure 8 the ion beam current and accelerator drain current are plotted as a function of total discharge power. The most efficient ion production occurs between 20 and 25 watts. Above 30 watts, additional increases in discharge power result in little further increase in beam current. The accelerator drain current showed a peak which roughly coincided with the steepest portion of voltage-current curve.

The current carrying capabilities of the grids were evaluated by the method presented in reference 13. The net accelerating voltage, $V_{I}$, and accelerator voltage, $v_{A}$, were decreased while maintaining a constant $\mathrm{V}_{I} / \mathrm{V}_{I}+\left|\mathrm{v}_{\mathrm{A}}\right|$ ratio of 0.67 . The discharge power was adjusted to hold the beam current constant and the accelerator drain current was measured. The beam current and the Hg neutral flow were held constant to maintain fixed prope1lant utilization. When the total voltage was too low to focus the fons into the accelerator holes $\mathrm{J}_{\mathrm{A}}$ increased rapidly. The minimum total voltage above the defocusing point was plotted against the thruster beam current in figure 9. Minimum voltage points were obtained for three different propellant flow rates and for five different utilizations. Ion beam current is linear with respect to total voltage with a slope of $0.37 \mathrm{~mA} /$ volt. This result is consistent with the results on $30 \mathrm{~cm}$ dished grids.(13)

In figure 10 , the beam current is plotted with respect to the net accelerating voltage. In all cases the accelerator voltage was held constant at -500 volts. Three curves are shown corresponding to thruster operating levels appropriate to $8.9 \mathrm{mN}$ $(2 \mathrm{mlb}), 6.7 \mathrm{mN}(1.5 \mathrm{mlb})$, and $5.1 \mathrm{mN}(1.14 \mathrm{mlb})$ operating levels. All curves show very little increase in beam current between 500 and 1200 volts.

The results shown in figures 9 and 10 indicate that at the $8 \mathrm{~cm}$ operating points of $4.45 \mathrm{mN}$ and $8.9 \mathrm{mN}$ the grid system is operating far below its perveance limit.

The accelerator voltage, $V_{A}$, was also varied at constant net accelerating voltage, $V_{I}$, of 1200 volts for three different values of $\mathrm{Hg}$ flow rates. Both the beam current and the accelerator drain current were measured at each value of accelerator voltage (fig. 11). In the figure, beam current and drain current are plotted so that direct comparisons can be made. The open symbols are beam-current and the closed are drain current. As expected, both beam current and accelerator drain current were increasing functions of accelerator voltage. Changing $v_{A}$ from -250 volts to -1000 volts results in propellant utilization gain of 2 to $3 \%$. This was probably due to the penetration of sheath into discharge chamber as total voltage increased. Over the same interval of $V_{A}$ the accelerator drain current increased by $17.5,22.6$, and $36 \%$ for the three different flow levels, 174, 141, and $96 \mathrm{~mA}$, respectively. Over a $20000 \mathrm{hr}$ mission, the erosion from direct or charge exchange impingement might be a crucial factor and any reduction could represent a major increase in operational 1ife. It is therefore desirable to keep $\nabla_{A}$ low.

The backstreaming 1imit of the beam extraction system was measured at the three beam current flow levels. It was found to be on the order of -200 volts. Although it became more negative with increasing beam current from -180 to -220 volts, the increase does not severely impact thruster operation. This is in agreement with results found on thirty centimeter thrusters. (14)

The beam proftle was also measured at several accelerator voltages; $-1000,-500$, and -280 volts. A motor driven negatively biased planar molybdenum probe was used. The ion current intercepted by the probe was plotted as a function of the probe position on an $x-y$ recorder and 1s shown in figure 12 . The probe was positioned $71 \mathrm{~cm}$ or nearly nine grid diameters downstream of the thruster. The probe was perpendicular to the thrust axis and it translated $\pm 25 \mathrm{~cm}$ on each side of center. The half angle subtended by the probe translation was 19.5 degrees.

The resulting profiles for the $5.1 \mathrm{mN}$ $(1.14 \mathrm{mIb})$ and $8.9 \mathrm{mN}(2.0 \mathrm{mlb})$ thrust levels were qualitatively very simflar. Only the profile curves for the $8.9 \mathrm{mN}(2.0 \mathrm{mlb})$ level are shown in figure 12. The thruster beamlets become more focused as the accelerator voltage is decreased at fixed $V_{I}$. The increased focusing results in a more collimated beam. At $a V_{A}$ of -280 volts the intercepted probe current decreased by half in less than five degrees and to one tenth in under ten degrees. The corresponding values for -500 and $-1000 \mathrm{~V}$ levels of $\mathrm{V}_{\mathrm{A}}$ are $6.8^{\circ}$ and $11.2^{\circ}$, and $8.8^{\circ}$ and $17.2^{\circ}$, respectively.

The combination of lower drain current, improved focusing, and lower thrust losses make operation at high net to total voltage ratio very desirable.

\section{Concluding Remarks}

A computer analysis has indicated that an $8 \mathrm{~cm}$ diameter thruster represents a favorable compromise between weight and power restrictions, operational life, and thrust requirements. An $8 \mathrm{~cm}$ thruster has been designed and fabricated based on $5 \mathrm{~cm}$ thruster technology. Preliminary results are encouraging; at this early state of development the $8 \mathrm{~cm}$ thruster operates at higher propellant utillzations and lower discharge losses than the best achieved by the $5 \mathrm{~cm}$ thruster. The dished double grid beam extraction system has demonstrated potential for operation well beyond the $2 \mathrm{mlb}$ thrust level. 
The major area for further development will be the discharge chamber. It is currently planned to investigate changes in performance by modifying the propellant flow distribution and by incorporating a magnetic baffle.

\section{Appendix - Symbols}

D thruster diameter, $\mathrm{cm}$

$I_{\text {sp }}$ specific impulse, sec

$\mathrm{J}_{\mathrm{A}}$ accelerator drain current, $\mathrm{mA}$

ion beam current, $\mathrm{A}$

$\mathrm{J}_{\mathrm{CH}}$

cathode heater current, A

${ }^{\mathrm{J}} \mathrm{CK}$

$\mathbf{J}_{\mathbf{E}}$

cathode keeper current, A

$\mathrm{J}_{\mathrm{NH}}$

$\mathrm{J}_{\mathrm{NK}}$

$\mathrm{K}$

ion beam current factor

$\mathrm{M}_{\mathrm{C}}$

total system mass assuming connected propellant tanks, $\mathrm{kg}$

$\mathrm{M}_{\mathrm{Hg}}$ mass of propellant, $\mathrm{kg}$

$M_{I} \quad$ tọtal system mass assuming independent propellant tanks, $\mathrm{kg}$

$M_{p c}$ mass of power conditioner, $\mathrm{kg}$

$M_{\text {sc }}$ mass of spacecraft, $\mathrm{kg}$

$M_{s p}$ mass of solar panel, kg

$\mathrm{M}_{\mathrm{TH}} \quad$ mass of ion thruster, $\mathrm{kg}$

$\mathrm{M}_{\mathrm{TK}}$ mass of independent propellant tank, $\mathrm{kg}$

$\mathrm{M}_{\text {TKC }}$ mass of connected propellant tank, kg

$P \quad$ thruster input power, $W$

T thruster operating time, hr

$\mathrm{V}_{\mathrm{A}}$ accelerator voltage, $\mathrm{V}$

$\mathrm{V}_{\mathrm{CH}}$ cathode heater voltage, $\mathrm{V}$

$\mathrm{V}_{\mathrm{CK}}$ cathode keeper voltage, $\mathrm{V}$

$v_{g}$ aeutralizer floating potential, $v$

$V_{I}$ net accelerating potential, $V$

$\Delta V_{I}$ discharge voltage, $V$

$\mathrm{v}_{\mathrm{NH}}$ neutralizer heater voltage, $\mathrm{V}$

$\mathrm{V}_{\mathrm{NK}}$ neutralizer keeper voltage, $\mathrm{V}$

$\mathrm{Y}$ mission length, yr

$\varepsilon_{I}$ electron volts per beam ion, eV/ion

$\eta_{p e} \quad$ power conditioner efficiency, dimensionless
$\eta_{U}$. Ion thrister mass : utilization effictency, dimensionless

$\phi$ thruster orientation with respect to north or south, rad

\section{References}

1. Nakan1sh1, S., "9700-Hour Durability Test of a 5-Centimeter-Diameter Ion Thruster," to be presented at this Conf.

2. Hyman, J., Jr., "SIT-5 System Development," Paper 72-492, Apr. 1972, AIAA, New York, N.Y.

3. Love11, R. R., and O'Malley, T. A., "Station Keeping of High Power Communication Satel1ites," TM X-2136, 1970, NASA, Cleveland, Oh1o.

4. Kaplan, M. H., "Al1-E1ectric Thruster Control of a Geostationary Communications Satellite which Employs Narrow-Beam Antennas," Paper 72-436, Apr. 1972, AIAA, New York, N.Y.

5. Kerslake, W. R., "Review of the Thruster Development at the Lewis Research Center - 1973," TM X-68202, 1973, NASA, Cleveland, Ohto.

6. Lathem, W. C., "A 5000-Hour Test of a GridTransition Beam-Deflection System for a $5-\mathrm{cm}-$ Diameter Kaufman Thruster," TM X-68185, 1973, NASA, Cleveland, Ohio.

7. Hudson, W. R., and Welgand, A. J., "Hollow Cathodes with Impregnated Porous Tungsten Inserts and Tips," to be presented at this Conf.

8. Kerslake, W. R., "Des1gn and Test of PorousTungsten Mercury Vapor1zers," Paper 72-484, Apr. 1972, AIAA, New York, N.Y; (also TN D-6782, 1972, NASA, Cleveland, Oh1o).

9. Wintucky, E. G., "H1gh Voltage Pulse Cathode Starting," to be presented at this Conf.

10. Lathem, W. C., "Approximate Analysis of the Effects of Electrode Misalinement on Thrust Vector Control in Kaufman Thrusters," Paper 68-69, Jan. 1968, AIAA, New York, N.Y.

11. Lathem, W. C., and Adam, W. B., "Theoret1cal Analysis of a Grid-Translation Beam Deflection System for a 30-Centimeter-Dlameter Kaufman Thruster," TM X-67911, 1971, NASA, Cleveland, Oh10.

12. Kaufman, H. R., "Ion-Thruster Propellant Ut1lization," Journal of Spacecraft and Rockets, Vol. 9, No. 7, July 1972, Pp. 511-517.

13. Kerslake, W. R., "Accelerator Grid Tests on an Electron-Bombardment Ion Rocket," TN D-1168, 1962, NASA, Cleveland, Ohio.

14. Rawlin, v., "30-Centimeter Dished Grid Exp.," to be presented at this Conf. 
Table 1. Performance parameters, efflciencles, and subsystem masses for varlous thruster dlameters

\begin{tabular}{|c|c|c|c|c|c|c|c|c|}
\hline $\begin{array}{l}\mathrm{D} \\
\mathrm{Cm}\end{array}$ & $\begin{array}{l}\text { ET: } \\
\text { eV/ion }\end{array}$ & $\mathrm{J}_{\mathrm{B}}$ at $\underset{\mathrm{K}}{\mathrm{K}}=1$, & $\mathrm{J}_{\mathrm{B}}$ at $\mathrm{K}=2$, & $\begin{aligned} P & \text { at } K=1 \\
\text { and } I_{s p_{W}} & =2500\end{aligned}$ & $\eta_{\mathrm{U}}$ & $n_{\mathrm{pc}}$ & $\begin{array}{c}\mathrm{M}_{\mathrm{TH}} \\
\mathrm{kg}\end{array}$ & $\begin{array}{l}\mathrm{M}_{\mathrm{pc}} \text { : } \\
\mathrm{kg}\end{array}$ \\
\hline $\begin{array}{r}5 \\
8 \\
10 \\
15 \\
20\end{array}$ & $\begin{array}{l}350 \\
323 \\
305 \\
260 \\
215\end{array}$ & $\begin{array}{c}0.028 \\
.0717 \\
.112 \\
.252 \\
.448\end{array}$ & $\begin{array}{r}0.056 \\
.143 \\
.224 \\
.504 \\
.896\end{array}$ & $\begin{array}{r}64.5 \\
134.5 \\
280.5 \\
375.2 \\
591.0\end{array}$ & $\begin{array}{r}0.700 \\
.718 \\
.730 \\
.760 \\
.790\end{array}$ & $\begin{array}{r}0.797 \\
.820 \\
.842 \\
.851 \\
.864\end{array}$ & $\begin{array}{l}1.135 \\
1.816 \\
2.270 \\
3.405 \\
4.540\end{array}$ & $\begin{array}{r}4.789 \\
6.626 \\
8.461 \\
9.191 \\
10.327\end{array}$ \\
\hline
\end{tabular}

Table 2. Total system mass minimums and associated optimum parameters for various spacecraft masses assuming $I_{\mathrm{sp}}=2750 \mathrm{sec}, \mathrm{Y}=5 \mathrm{yr}$, and $\phi=0$

\begin{tabular}{|c|c|c|c|c|c|c|c|c|c|c|}
\hline \multirow{2}{*}{$\begin{array}{c}\mathrm{M}_{\mathrm{sc}} \\
\mathrm{kg}\end{array}$} & \multicolumn{5}{|c|}{ Independent propellant tankage } & \multicolumn{2}{|c|}{ Connected } & \multicolumn{3}{|c|}{ propellant tankage } \\
\hline & ${ }_{\mathrm{kg}}^{\mathbf{M}_{\mathbf{g}}}$ & D, & K & $\underset{\mathrm{A}}{\mathrm{J}_{\mathrm{B}}}$, & $\begin{array}{l}\text { T, } \\
\text { hr }\end{array}$ & $\begin{array}{r}\mathrm{M}_{\mathrm{c}}, \\
\mathrm{k}_{\mathrm{g}}\end{array}$ & $\begin{array}{l}\mathrm{D}, \\
\mathrm{cm}\end{array}$ & $\mathbf{K}$ & $\underset{\mathrm{A}}{\mathrm{J}_{\mathrm{B}},}$ & $\begin{array}{l}\text { T, } \\
\text { hr }\end{array}$ \\
\hline 500 & & 4 & & & & & & & & \\
\hline 750 & & 5 & & & 61 & & 5 & & & \\
\hline 1000 & 48.9 & 6 & 1.7 & .069 & 6089 & 37.4 & 6 & 1.6 & .069 & 6499 \\
\hline 1250 & 57.5 & 6 & $>2.2$ & $>0.089$ & 5868 & 43.2 & 6 & 2.0 & .081 & 6499 \\
\hline 1500 & 66.5 & 7 & -2.0 & -.110 & 5731 & 49.3 & 7 & 1.8 & .099 & 6414 \\
\hline 1750 & 74.9 & 7 & $>2.2$ & $>0.121$ & 6102 & 55.0 & 7 & $>2.2$ & $>0.121$ & 6102 \\
\hline 2000 & 83.5 & 8 & -2.0 & .143 & 5911 & 60.7 & 8 & -1.8 & -.129 & 6618 \\
\hline
\end{tabular}

Table 3. Total system mass minimums and associated optimum parameters for various spacecraft masses assuming use of two $8 \mathrm{~cm}$ thrusters $(D=8 \mathrm{~cm})$, $I_{s p}=2750 \mathrm{sec}, Y=5 \mathrm{yr}$, and $\phi=0$

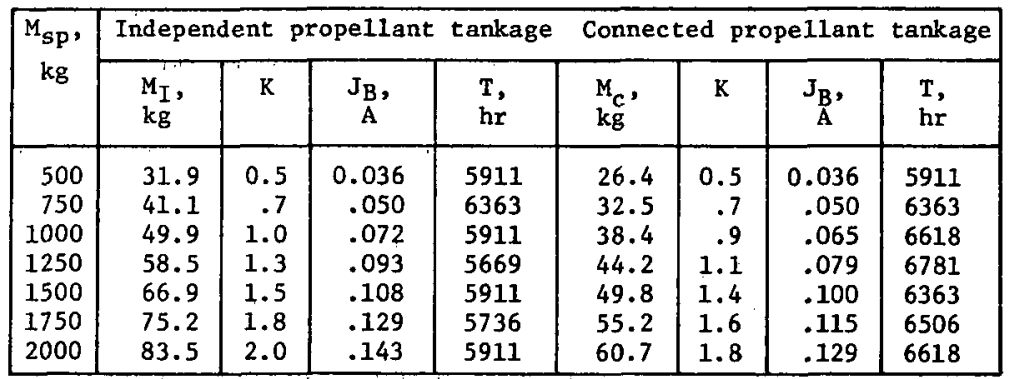


Table $4.8 \mathrm{~cm}$ thruster parameters compared w1th SIT-5 parameters

\begin{tabular}{|c|c|c|c|c|}
\hline & $\begin{array}{c}5 \mathrm{~cm} \\
\text { performance }\end{array}$ & $\begin{array}{c}8 \mathrm{~cm} \\
\text { performance } \\
\text { goals }\end{array}$ & \multicolumn{2}{|c|}{$\begin{array}{c}8 \mathrm{~cm} \\
\text { performance }\end{array}$} \\
\hline Thrust $^{\star}$ (ideal), mlb & 0.40 & 1.14 & 1.14 & 2.06 \\
\hline Specific impulse, ${ }^{*}$ sec & 2432 & 2804 & 2530 & 2870 \\
\hline Total input power, $\mathrm{W}$ & 70.0 & 122.2 & 154.6 & 232 \\
\hline Total efficiency, $\%$ & 30.5 & 57.5 & 41.0 & 55.8 \\
\hline Power efficiency, $\%$ & 46.8 & 71.3 & 56.4 & 67.7 \\
\hline Total utilization, * $\%$ & 65.0 & 80.6 & 72.7 & 82.5 \\
\hline Discharge utilization, * $\%$ & 68.8 & 86.4 & 77.5 & 88.5 \\
\hline Total neutral flow, mA & 36.0 & 89.3 & 99.0 & 157.7 \\
\hline Power/thrust, ${ }^{\star} \mathrm{W} / \mathrm{m} 1 \mathrm{~b}$ & 175 & 107 & 135.5 & 112.5 \\
\hline eV/Ion excluding keeper, $\mathrm{V}$ & 607 & 294 & 567 & 363 \\
\hline eV/1on including keeper, $\mathrm{V}$ & 825 & 328 & 608 & 382 \\
\hline Beam current, $\mathrm{J}_{\mathrm{B}}, \mathrm{mA}$ & 23.4 & 72 & 72 & 130 \\
\hline Net accelerating voltage, $v_{T}, v$ & 1409 & 1220 & 1220 & 1220 \\
\hline Neutralizer floating potential, $v_{g}, v$ & -9 & -10 & -8 & -10 \\
\hline Output beam power, $W$ & 32.7 & 87.1 & 87.1 & 157.5 \\
\hline Accelerator voltage, $V_{A}, V$ & -700 & -500 & -500 & -500 \\
\hline Accelerator drain current, $J_{A}, m A$ & 0.082 & 0.23 & 0.135 & 0.27 \\
\hline Accelerator drain power, $W$ & 0.17 & 0.40 & 0.23 & 0.46 \\
\hline Discharge voltage, $\mathrm{V}_{\mathrm{I}}, \mathrm{V}$ & 40 & 40 & 40 & 33 \\
\hline Emission current, $\mathrm{J}_{E}, \mathrm{~A}$ & 0.355 & 0.53 & 1.02 & 1.43 \\
\hline Discharge power, $\mathrm{W}$ & 14.2 & 21.2 & 0.8 & 47.2 \\
\hline Cathode: & & & & \\
\hline Keeper voltage, $\mathrm{v}_{\mathrm{CK}}, \mathrm{V}$ & 12.8 & 10.0 & 15.0 & 12.0 \\
\hline Keeper current, $\mathrm{J}_{\mathrm{CK}}, \mathrm{A}$ & 0.400 & 0.240 & 0.200 & 0.20 \\
\hline Keeper power, W & 5.12 & 2.4 & 3.0 & 2.4 \\
\hline Heater voltage, $\mathrm{v}_{\mathrm{CH}}, \mathrm{V}$ & 0 & 0 & 0 & 0 \\
\hline Heater current, $\mathrm{J}_{\mathrm{CH}}, \mathrm{A}$ & 0 & 0 & 0 & 0 \\
\hline Heater power, W & 0 & 0 & 0 & 0 \\
\hline Vaporizer voltage, $v_{C V}, V$ & 4.7 & 4.0 & 2.0 & 2.1 \\
\hline Vaporizer current, $\mathrm{J}_{\mathrm{CV}}, \mathrm{A}$ & 2.45 & 1.0 & 2.3 & 2.3 \\
\hline Vaporizer power, $\mathrm{W}$ & 11.5 & 4.0 & 4.6 & 4.8 \\
\hline Flow rate, mA & 34.0 & 83.3 & 93.0 & 147 \\
\hline Neutralizer: & & & & \\
\hline Keeper voltage, $\mathrm{V}_{\mathrm{CK}}, \mathrm{V}$ & 13.5 & 14.1 & 18.6 & 16.6 \\
\hline Keeper current, $J_{C K}$, A & 0.360 & 0.360 & 0.50 & 0.5 \\
\hline Keeper power, W & 4.86 & 5.08 & 9.3 & 8.3 \\
\hline Heater voltage, $\mathrm{v}_{\mathrm{CH}}, \mathrm{V}$ & 0 & 0 & 3.5 & 4.0 \\
\hline Heater current, $\mathrm{J}_{\mathrm{CH}}, \mathrm{A}$ & 0 & 0 & 1.5 & 1.6 \\
\hline Heater power, $\mathrm{W}$ & 0 & 0 & 5.25 & 6.4 \\
\hline Vaporizer voltage, $\mathrm{V}_{\mathrm{NV}}, \mathrm{V}$ & 1.65 & 1.65 & 2.0 & 2.1 \\
\hline Vaporizer current, $\mathrm{J}_{\mathrm{NV}}, \mathrm{A}$ & 0.77 & 0.77 & 1.85 & 1.9 \\
\hline Vaporizer power, $W$ & 1.27 & 1.27 & 3.70 & 4.00 \\
\hline Flow rate, $\mathrm{mA}$ & 2.0 & 6.0 & 6.0 & 10.7 \\
\hline Neutralizer coupling power, $\mathrm{W}$ & 0.21 & 0.72 & 0.58 & 1.3 \\
\hline
\end{tabular}

* Accounting for neutralizer floating potential but neglecting beam divergence and double ionization. 


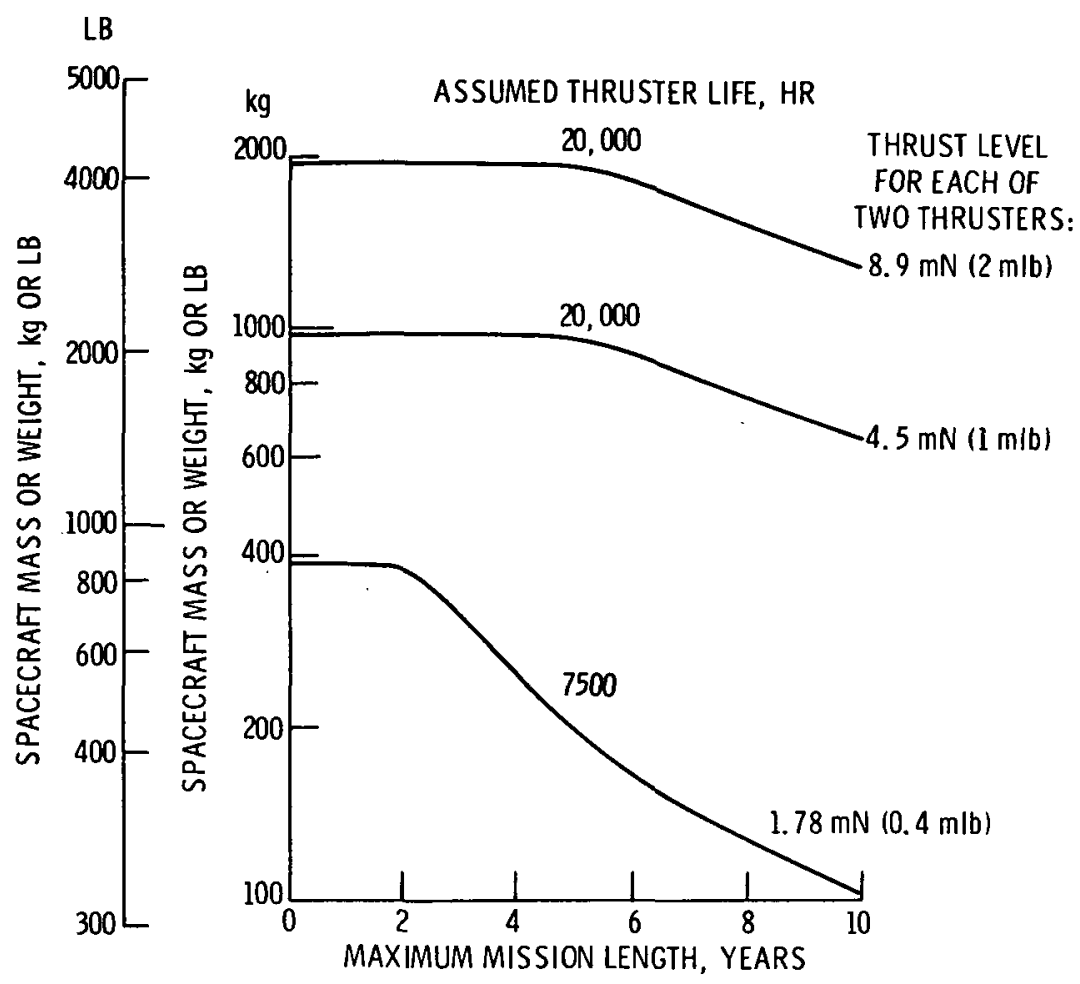

Figure 1. - Comparison of the maximum north-south station-keeping capabilities.

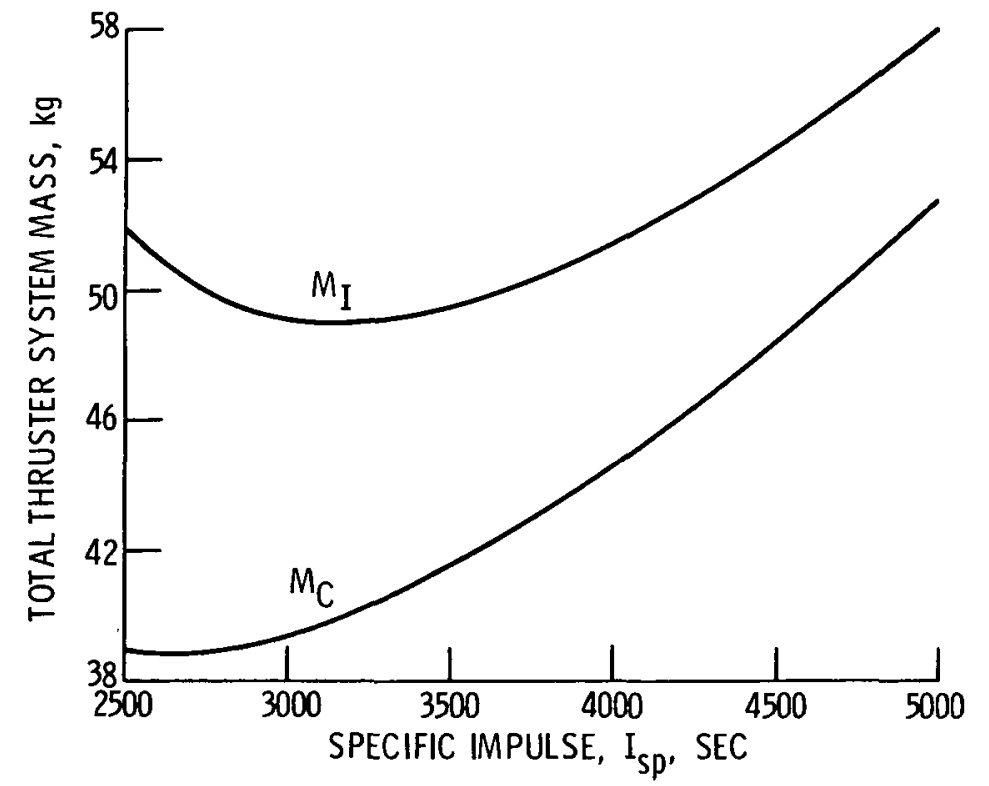

Figure 2. - Total thruster system mass for two $8 \mathrm{~cm}$ th rusters on a $1000 \mathrm{~kg}$ spacecraft with a five year mission, $\varphi=0$, $K=1\left(J_{B}=0.0717 \mathrm{~A}\right)$. 


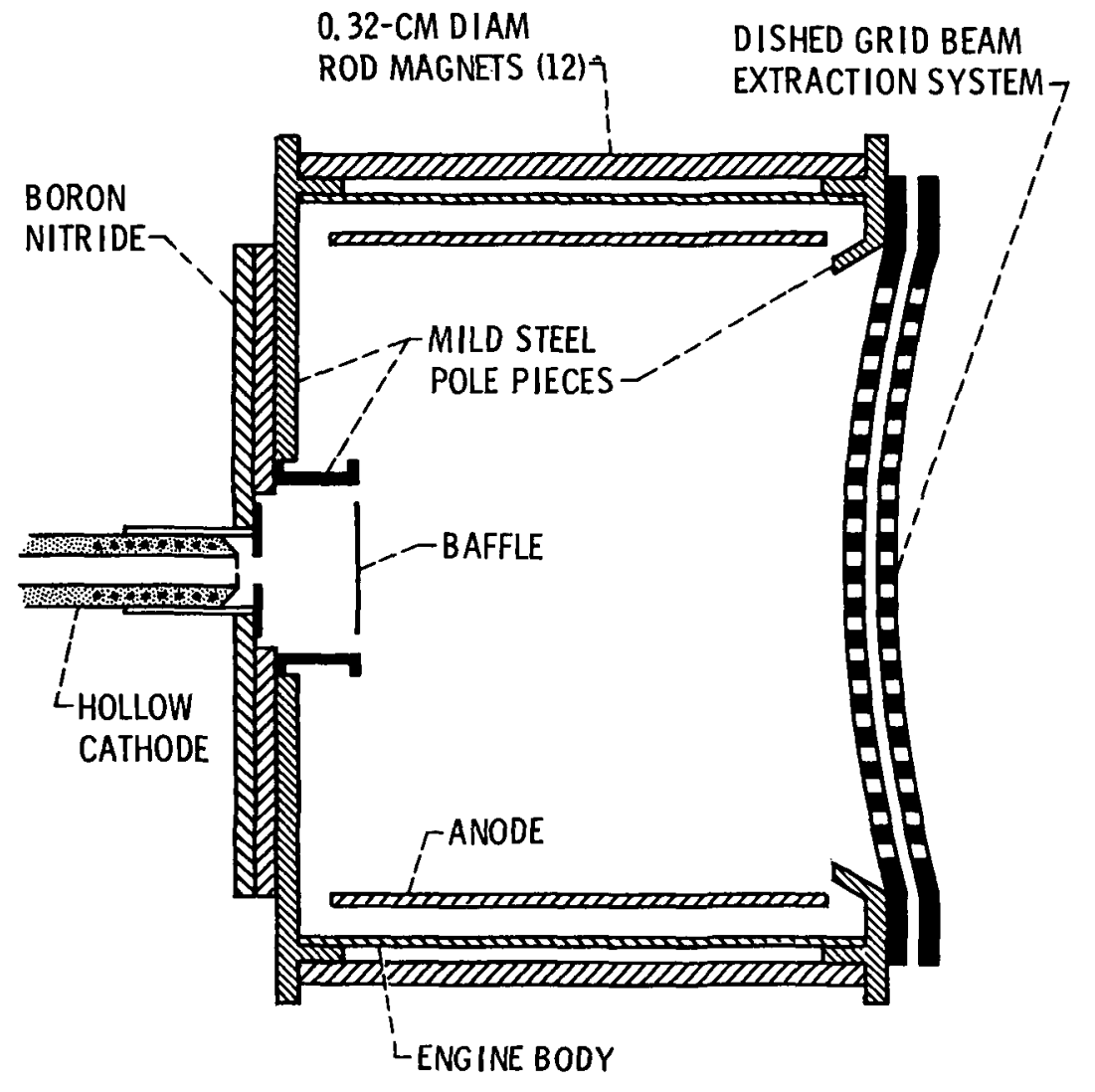

Figure 3. - Cross section of 8-cm-diameter thruster discharge chamber with the dished grid beam extraction system.

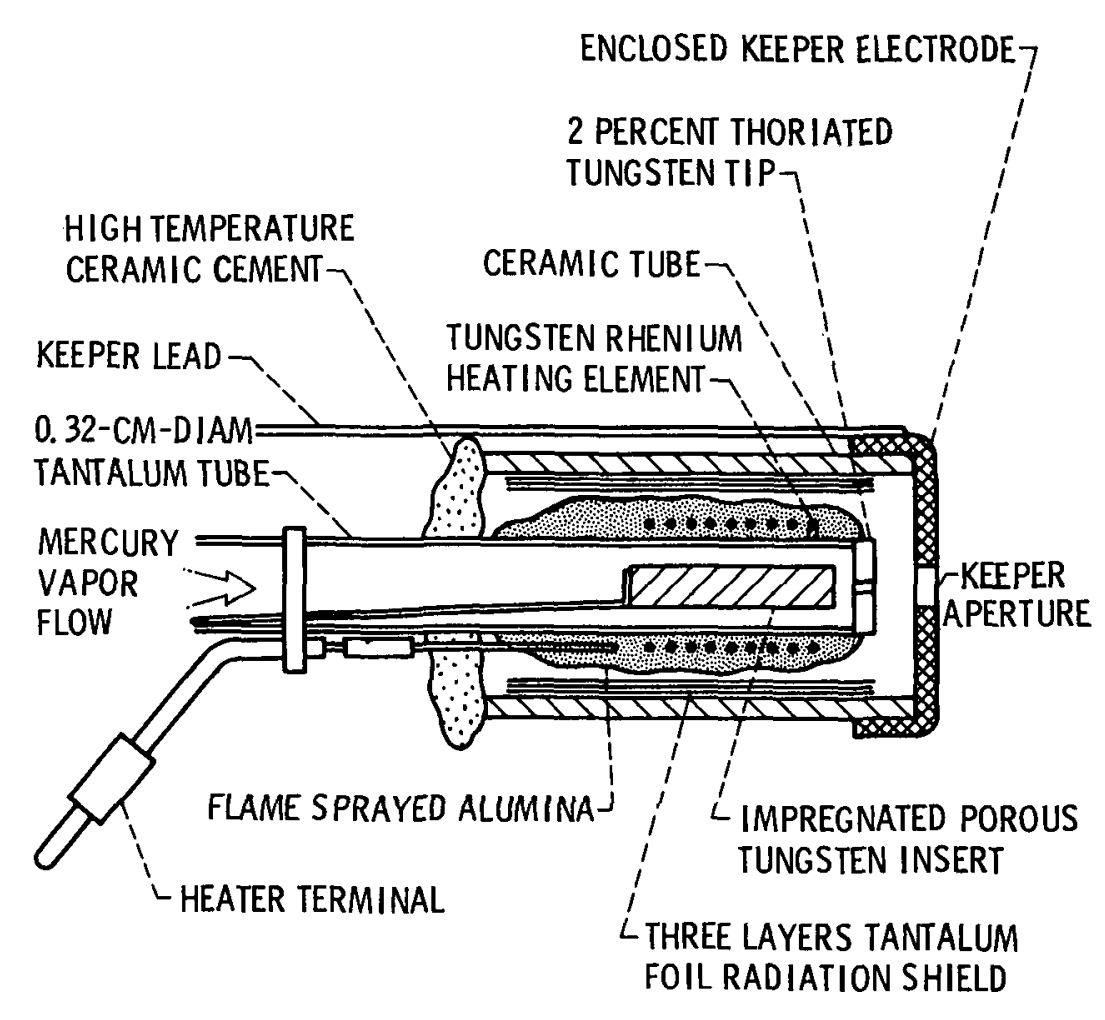

Figure 4. - Cross sectional view of main cathode and neutralizer configuration. 


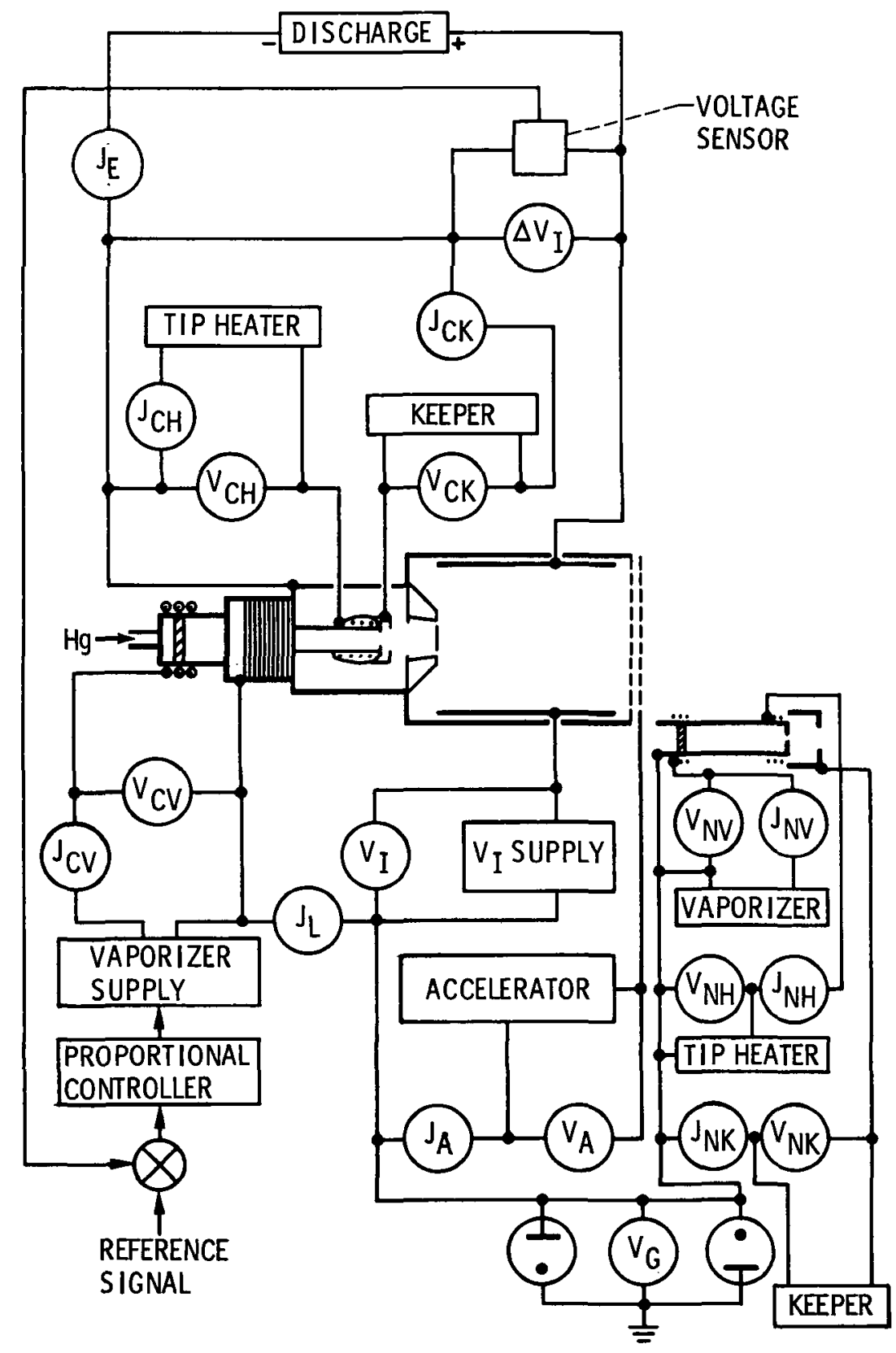

Figure 5. - Electrical circuit used for thruster testing.

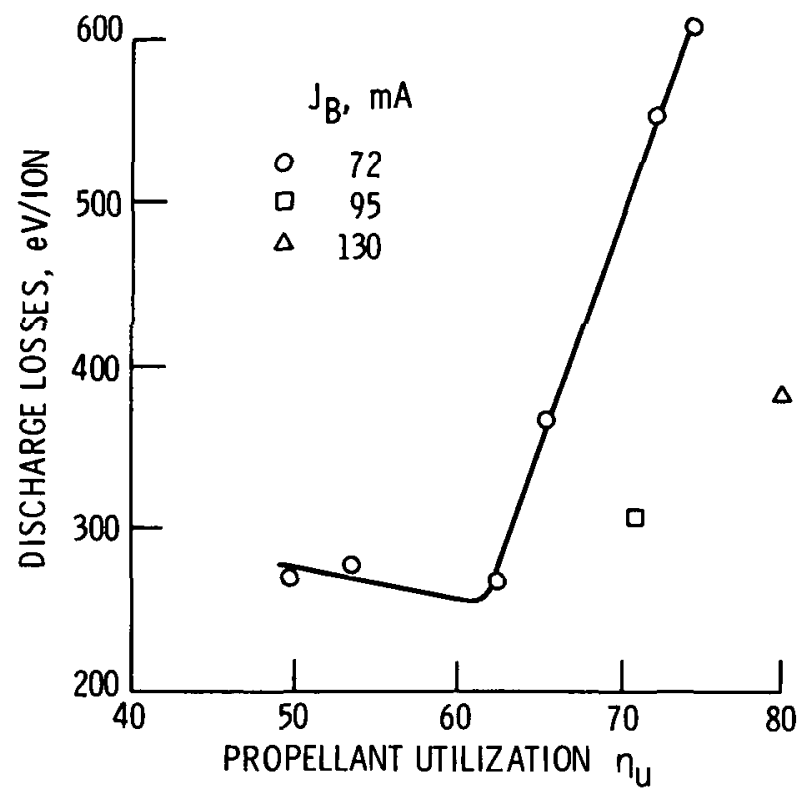

Figure 6. - Discharge chamber performance as a function of propellant utilization at a beam current of $72 \mathrm{ma} \mathrm{V}=1200$ volts and $V_{A}=$ -500 volts.

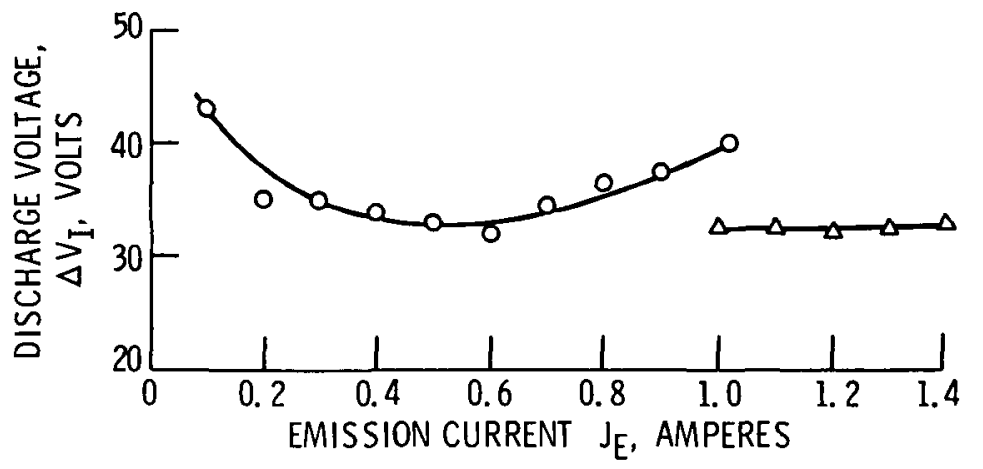

Figure 7. - Discharge voltage plotted versus emission current for $104 \mathrm{ma}$ of $\mathrm{Hg}$ flow, O; and $160 \mathrm{ma}$ of $\mathrm{Hg}$ flow, $\Delta$. The net accelerating voltage was 1220 volts and the accelerator voltage was -500 . 


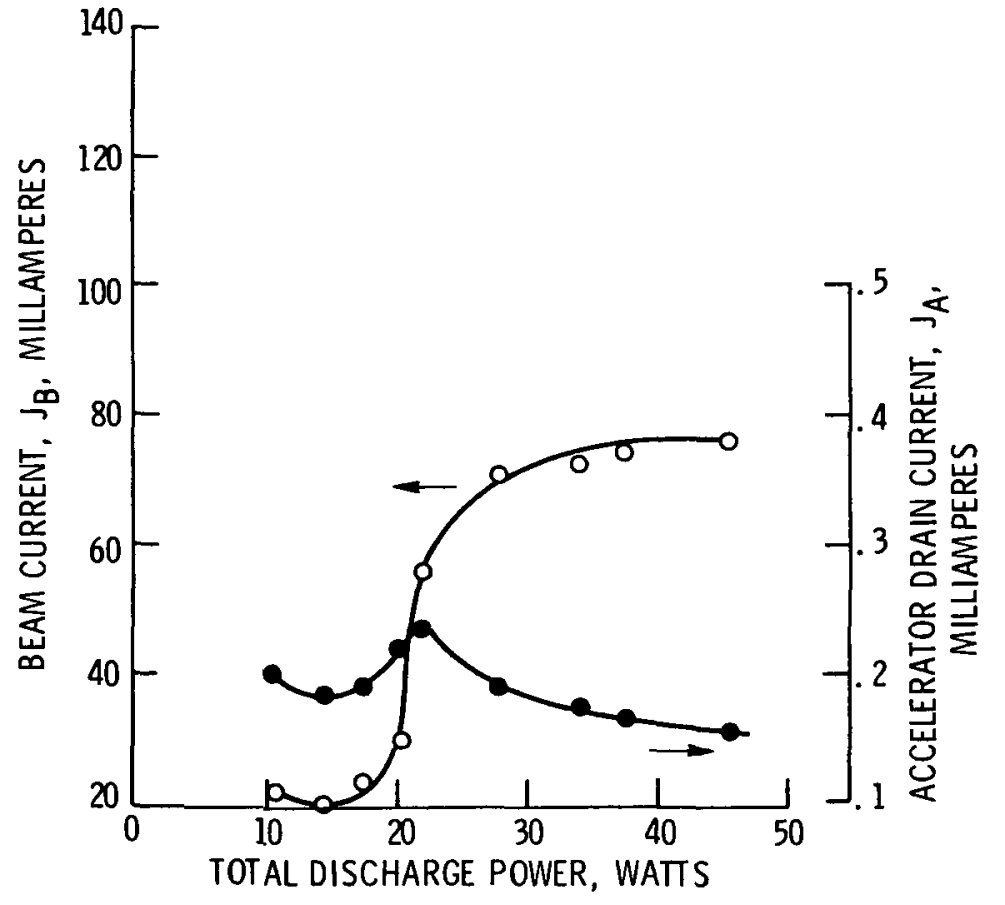

Figure 8. - Ion beam and accele rator drain currents as a function of total discharge power. The accelerator drain current is plotted simultaneously.

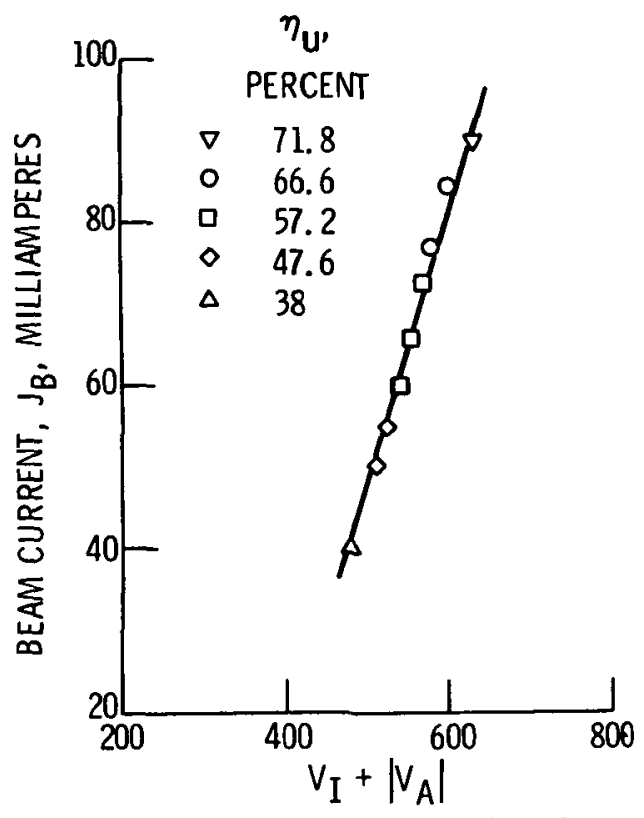

TOTAL ACCELERATING VOLTAGE

Figure 9. - A composite of grid performance operating points include several mass flow rates and efficiencies.

Hg FLOW RATE, $M A$

- 160

$\triangle 133$

口 96

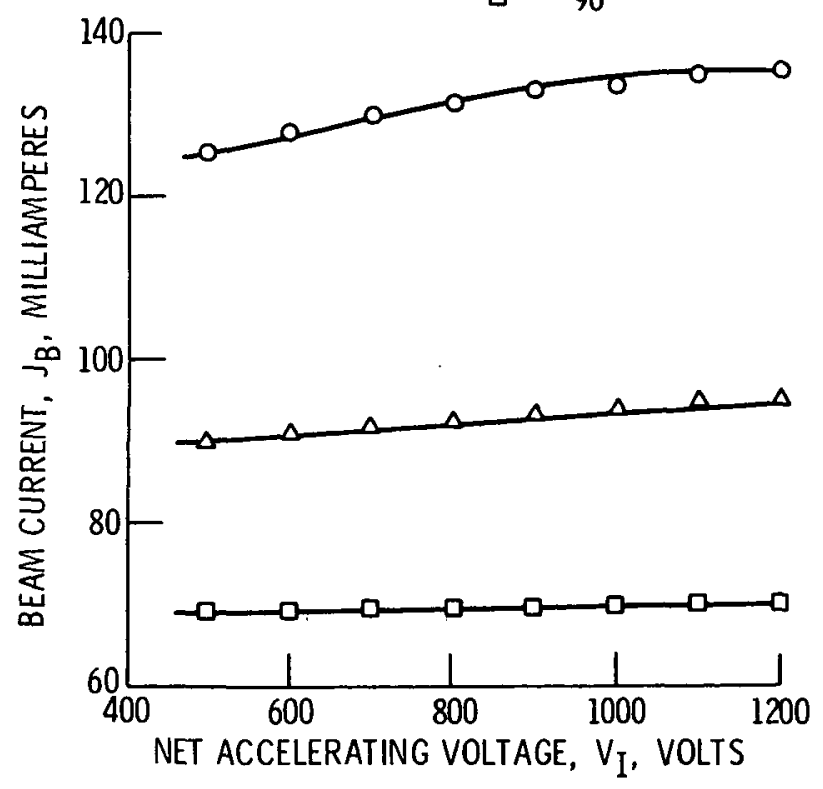

Figure 10. - The variation of beam current as a function of net accelerating voltage at appropriate mercury flow rates for thrust levels of $8.9 \mathrm{mN}$, and $4.4 \mathrm{mN}$. 


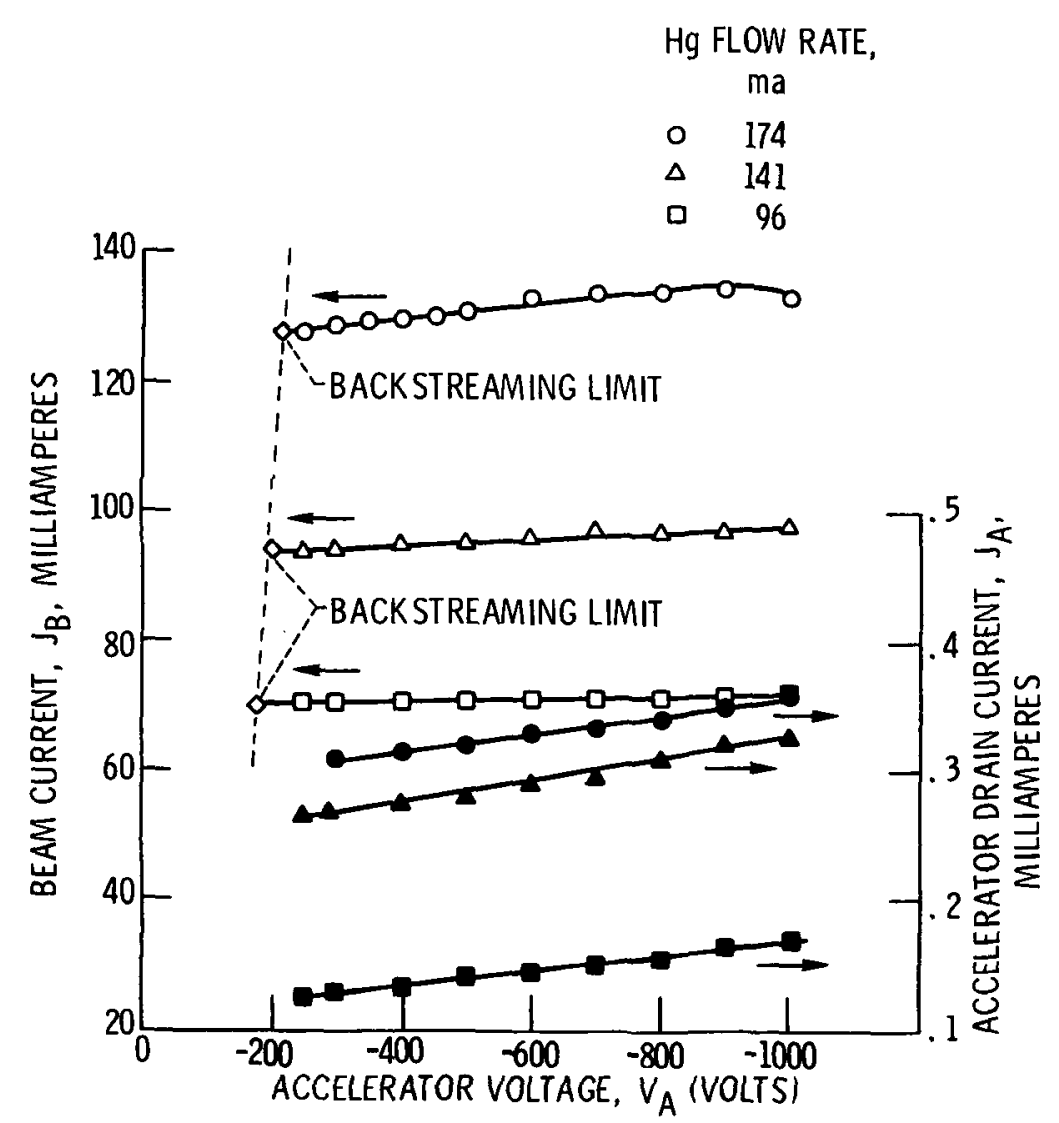

Figure 11. - The variation of beam current as a function of accelerator voltage. The corresponding accelerator drain is plotted simultaneously.

\begin{tabular}{|c|ccc|}
\hline $\begin{array}{c}\text { FRACTION } \\
\text { PEAK }\end{array}$ & \multicolumn{3}{|c|}{$V_{A}$} \\
\hline$\frac{1}{2}$ & $-280 \mathrm{v}$ & $-500 \mathrm{v}$ & $-1000 \mathrm{v}$ \\
$\frac{1}{10}$ & $9.9^{\circ}$ & $6.8^{\circ}$ & $8.8^{\circ}$ \\
\hline
\end{tabular}
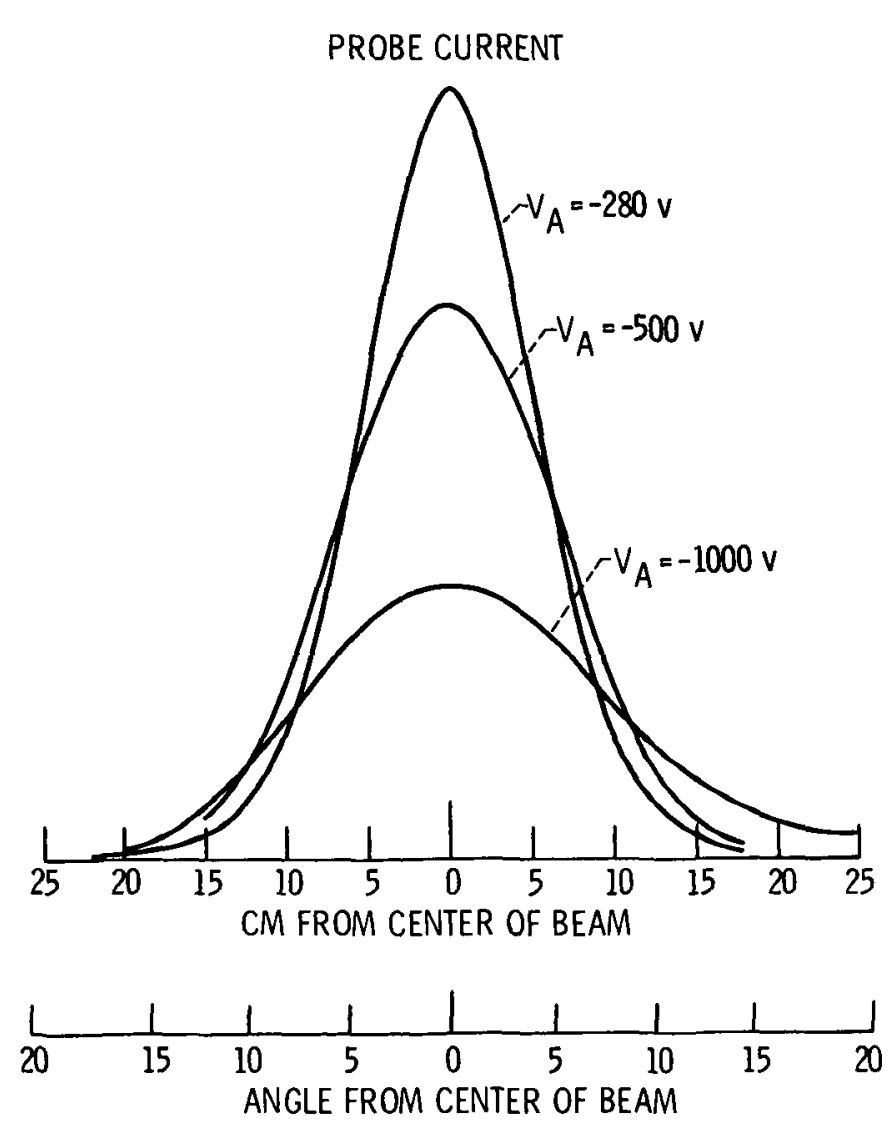

Figure 12. - Beam profile at three different accelerator voltages but with $V_{I}=1200$ volts, $J_{B}=130 \mathrm{ma}$, rake was at $71 \mathrm{~cm}$. Profiles very nearly the same $J_{B}=72 \mathrm{ma}$. 